FRANC ŽELJKO ŽUPANIČ, M.Sc.

E-mail: zupanic@sloveniacontrol.si

Slovenia Control, Slovenian Air Navigation Services, Ltd

Kotnikova 19a, 1000 Ljubljana, Slovenia

MAJA MEŠKO, Ph.D.

E-mail: maja.mesko@fm-kp.si

University of Primorska, Faculty of Management

Cankarjeva 5, 6000 Koper, Slovenia

IZTOK PODBREGAR, Ph.D.

E-mail: iztok.podbregar@fvv.uni-mb.si

University of Maribor,

Faculty of Criminal Justice and Security

Kotnikova 8, 1000 Ljubljana, Slovenia
Safety and Security in Traffic Preliminary Communication Accepted: July 8, 2011

Approved: Mar. 14, 2012

\title{
METHODOLOGY OF AN AIRCRAFT ACCIDENT RESPONSE SYSTEM ASSESSMENT
}

\begin{abstract}
The paper investigates the ability to learn from an aircraft accident as the opportunities for learning diminish with the decline in the accident rate. A safety compromising case is studied as the processes of aircraft accident intervention and recovery can degrade the ability of an aircraft accident investigation process to enhance aviation safety by revealing accident causation. In the case study an assessment of the Slovenian aircraft accident response system was made. For the purpose of evaluating the successfulness of aircraft accident intervention and effectiveness of recovery, a mode of aircraft accident response system requirements has been developed. Based on non-conformances identified by the model of requirements, remedial measures are proposed for the enhancement of the aircraft accident response system operation. Criteria for the definition of the transition from accident intervention to recovery are derived from the assessment findings in a manner not to impede the aircraft accident investigation effectiveness and efficiency.
\end{abstract}

\section{KEY WORDS}

aircraft accident, response system, intervention, recovery, investigation, crisis management

\section{INTRODUCTION}

The aircraft accident response system consists of aircraft accident intervention, recovery and investigation, which are subject areas falling within the scope of the paper. As the aircraft accident rate declines, the opportunity for learning from accidents diminishes, and the opportunity to develop effective accident investigation recommendations for the industry is also reduced [1]. Clearly reactive aviation safety management has to evolve into proactive safety management.
However, whenever an aircraft accident happens, lessons must be learned how to avoid its reoccurrence [2]; otherwise, the "accident lesson is much too expensive". The essence of the ability to learn from an aircraft accident is the provision of a functional response system which assures that the processes of aircraft accident intervention and recovery do not interfere with the aircraft accident investigation. The interference with the investigation lessens the ability to improve aviation safety by providing the reasons for the accident - and this is a general problem addressed in the paper. The quest for a solution to the problem is driven by the hypothesis that the role and importance of the safety aspect of the transition from intervention to recovery in the event of an aircraft accident is to significantly contribute to flight safety. The principle is thereby to protect the lives, health and safety of people and to keep public order.

When an accident happens, intervention is required which must then be followed by recovery. Intervention is an organized act of intervening by one or more rescue units or departments with the purpose of protecting and rescuing people and their property, cultural heritage and the environment and preventing further damage and other consequences of the accident [3]. When an imminent danger to life or health of people, animals, property, heritage and the environment is eliminated, and when the risk of further injury is removed or reduced, the intervention is completed. It is followed by recovery, the purpose of which is to eliminate the consequences of the accident [3]. It includes the necessary measures and activities to ensure that the basic living conditions and sustainable recovery of affected areas are provided for and that 
the original state is re-established or even further improved.

Crisis is a situation in which confidence in something or someone is inhibited to such an extent that there are serious doubts of its existence [4, 5, 6, 7, 8]. Since crisis appears in different forms, one generally accepted definition of the term cannot be accepted [9]. However, there are three characteristics of each crisis. The first characteristic is suddenness. Although certain signs of crisis can be observed prior to its outbreak, crisis always comes unexpectedly. Another feature is uncertainty, strongly influenced by the provision of good quality information for decisionmaking. The third common characteristic of all crises is time pressure, which requires prompt decision-making and stress management by all participants in the crisis. Crisis is a term often used to describe difficult and dangerous situations critical for the future [10]. As an aircraft accident is characterized by suddenness, unexpectedness, potentially difficult access to the accident site and the possibility that all passengers and crew members and residents of populated areas could be victims, it is a crisis situation, as it complies with crisis-specific criteria.

\section{CASE STUDY: SLOVENIAN RESCUE SYSTEM}

\subsection{Availability of protection, rescue and relief forces}

Protection, rescue and relief forces are available human resources of the state and other organizations (associations, services, companies, institutions or local communities) intended to protect, rescue and relieve from disasters, including an aircraft accident. By definition of the core national plan [11], the res- cue system objective is to reduce, mitigate or prevent the casualties and harmful consequences of an aircraft accident. The system entities are organized by local communities, the state and certain companies with regard to the threat posed to their areas (associations and services), or with regard to the risk related to the activities they perform (companies, institutions and other organizations). The Administration for Civil Protection and Disaster Relief, the Police and the Slovenian Armed Forces constitute the system backbone. The system is organized to utilize the facilities, services and expertise of intergovernmental, governmental or non-governmental organizations and civil society in order to enhance the complementarity of efforts in achieving the system objectives effectively.

Response system entities are engaged in protection, rescue and relief and public services, following a decision of the competent authority or local government body.

\subsection{Existing response system fact-finding statistics}

The operational entity personnel were interviewed to obtain information about the existing operational measures designed to ascertain the requirements of an aircraft accident intervention and recovery system. Individuals from the target groups have already been or could be engaged in aircraft accident intervention or recovery (Figure 1).

In addition to most respondents (Figure 1) that found their competences or responsibilities specified in detail, nobody considered the competences or responsibilities in the event of an accident as non-existent. This is a good indicator of their understanding of responsibilities and competences, as it helps avoid mistakes resulting from "the transfer of responsibility". For example, when someone thinks that some-

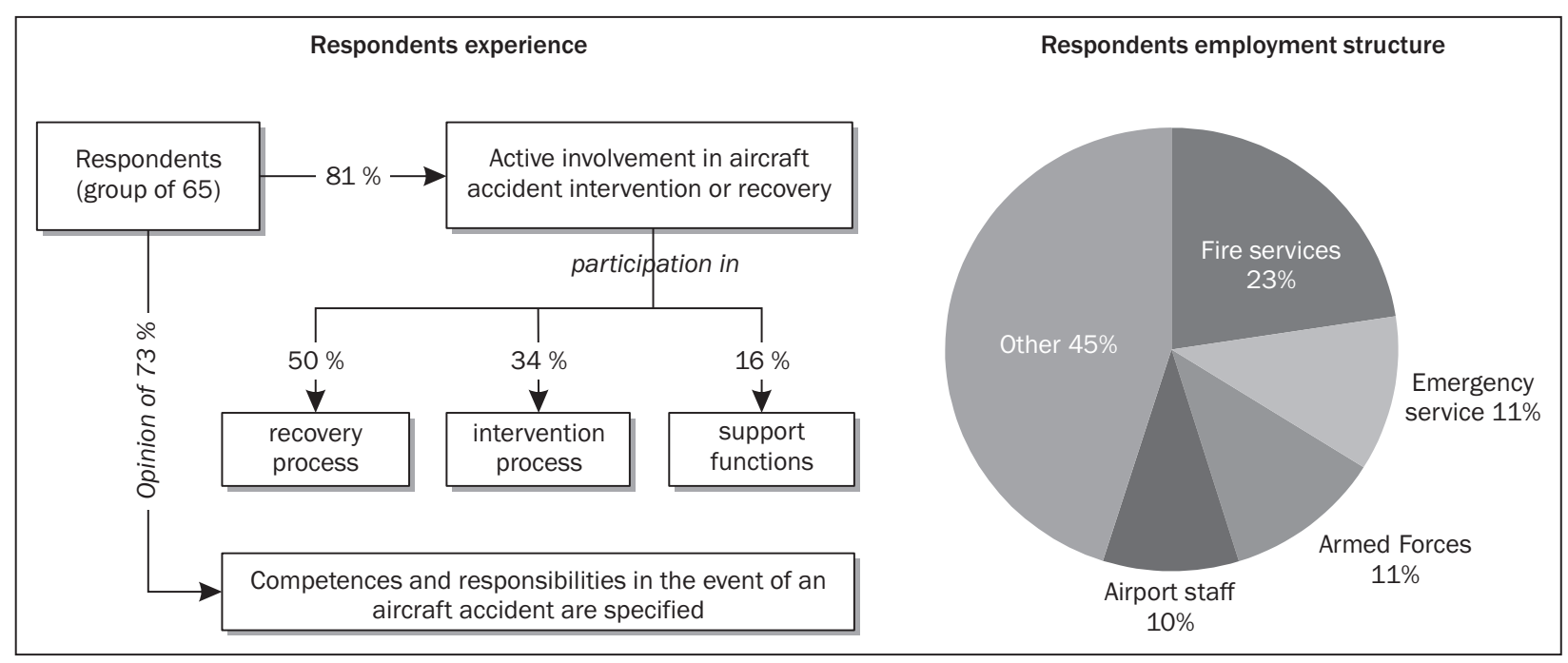

Figure 1 - Respondents competence check-up 
Table 1 - Ranking of factors important in the process of aircraft accident intervention and recovery

\begin{tabular}{||c|l|c||}
\hline \hline Rank & \multicolumn{1}{|c|}{$\begin{array}{c}\text { Safety factors important in the process of air- } \\
\text { craft accident intervention and/or recovery }\end{array}$} & $\begin{array}{c}\text { Ranked as the most important safety } \\
\text { factor by the portion of respondents }\end{array}$ \\
\hline \hline 1 & $\begin{array}{l}\text { Definition of criteria for the transition from air- } \\
\text { craft accident intervention to recovery }\end{array}$ & $36 \%$ \\
\hline 2 & Properly trained and qualified staff & $24.5 \%$ \\
\hline 3 & $\begin{array}{l}\text { Assessment of the situation and the consequences of an } \\
\text { aircraft accident for people and the environment }\end{array}$ & $17 \%$ \\
\hline 4 & Proper determination of competences & $12 \%$ \\
\hline 5 & Determination of emergency measures for risk mitigation or reduction & $3 \%$ \\
\hline 6 & Setting up of an appropriate infrastructure & $3 \%$ \\
\hline 7 & $\begin{array}{l}\text { Definition of measures for recovery of an aircraft accident site } \\
\text { covery of an aircraft accident site }\end{array}$ & $1.5 \%$ \\
\hline 8 & $\begin{array}{l}\text { Deadline for the reconstruction of the damaged } \\
\text { area at the aircraft crash site determination }\end{array}$ & $1.5 \%$ \\
\hline 9 & Protection of property & $1.5 \%$ \\
\hline
\end{tabular}

thing is not their responsibility and the task remains undone. It is namely the case where the responsibility is transferred from one person to another.

A survey conducted on the issue of the entire sequence of an aircraft accident intervention, investigation and recovery identified a systematic problem. While the majority of the interviewees (81\%) have already been actively involved in an aircraft accident response, thus having direct practical experience (Figure 1), only $56 \%$ of the respondents did not identify any problem areas in the aircraft accident response system (Figure 2). For the latter group it may be presumed that they know exactly what their competences and responsibilities are and when their work is completed. However, a significant fraction (36\%; Figure 2) of interviewees responded, that deficiencies in procedures of transition from intervention to aircraft accident recovery do exist. Since those deficiencies directly influence an aircraft accident investigation and thus reactive safety management, there should be no lack of understanding. Additionally, doubtfulness leading to the "I don't know" response (Figure 2) suggests that the respondents lack knowledge in both, intervention and recovery.

On the basis of the collective experience of the interviewees the factors important for the effectiveness of aircraft accident intervention and recovery process-

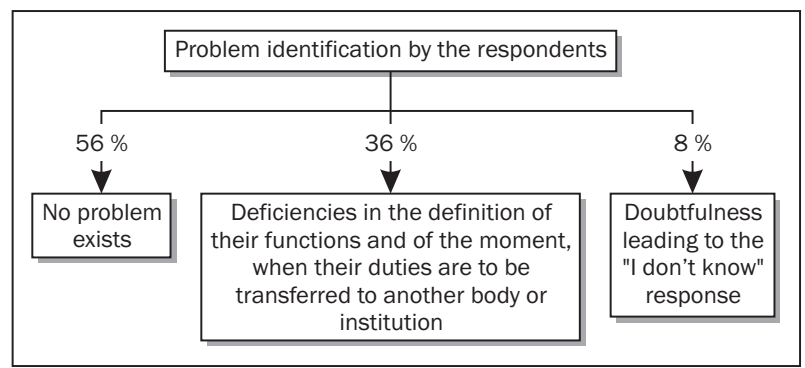

Figure 2 - Response system problem area identification es are ranked and detailed in Table 1. The leading priority is the definition of criteria for the transition from aircraft accident intervention to recovery.

\section{AIRCRAFT ACCIDENT RESPONSE SYSTEM ANALYSIS}

\subsection{Design-Functionality-Performance- Mission model of aircraft accident response system requirements}

The design, functionality, performance and mission (DFPM) model of aircraft accident response system requirements is introduced in Table 2. It was inspired by the:

- aircraft accident rehearsal model of [12],

- intervention strategies implemented to prevent repetitions of similar clinical incidents [13],

- Hewlett-Packard FURPS+ model for classifying software requirements $[14,15]$.

While the FURPS+ model is analysing functionality, usability, reliability, performance, supportability, as well as design, implementation, interface and physical requirements $[14,15]$, the DFPM model classifies the functional and non-functional requirements into design, functionality, performance and mission requirements of an aircraft accident response system (Table 2).

The DFPM model is answering the basic questions of minimal operational requirements imposed on the aircraft accident intervention and recovery system:

- Where will the system and how will its components be used?

- How will the system's mission objective be accomplished and what are the critical system parameters to accomplish the mission? 
Table 2 - DFPM model of aircraft accident response system requirements

DFPM model of an aircraft accident response system requirements

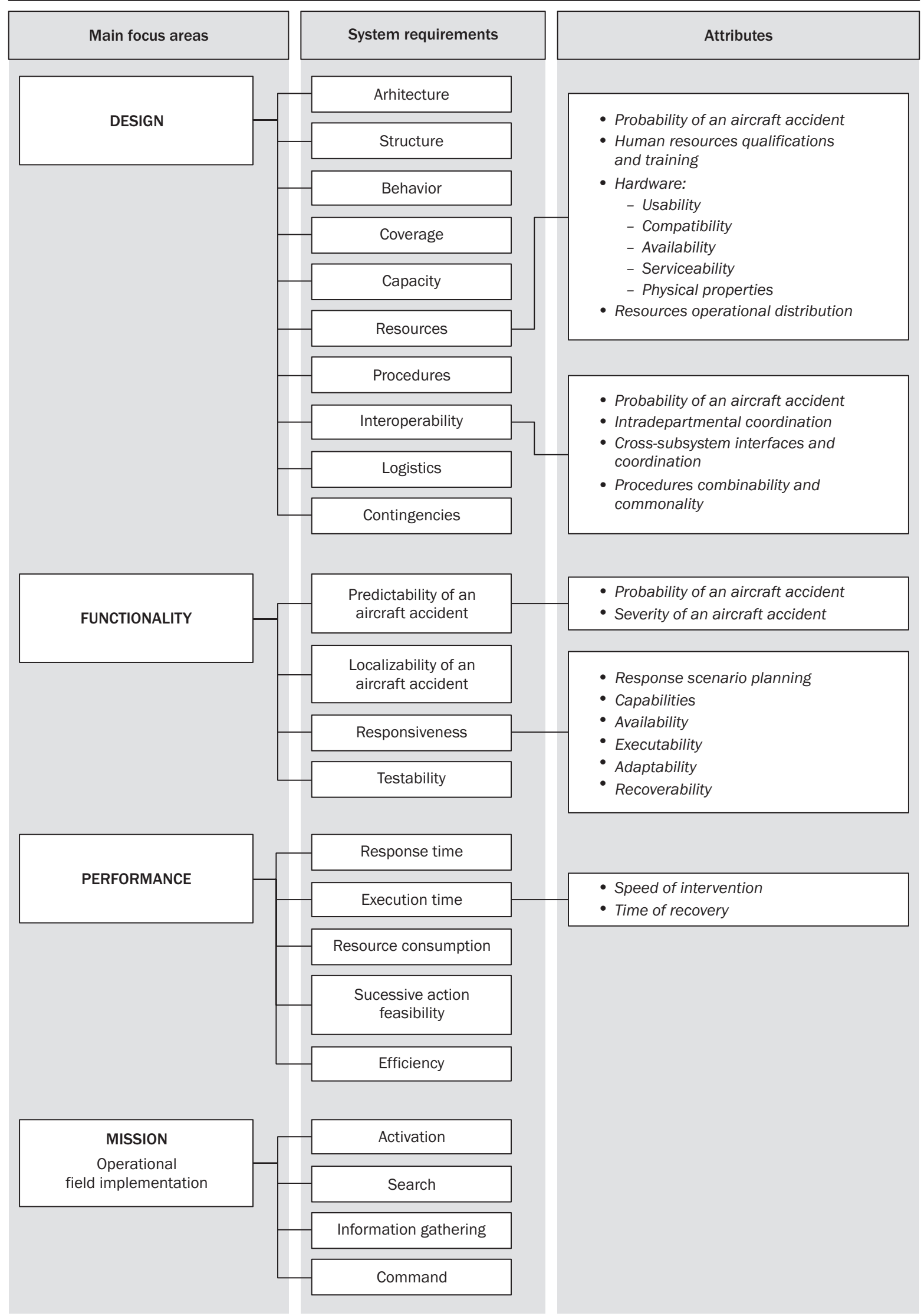


- How effective or efficient must the system be in performing its mission?

- How long will it be in use and in what environments will the system be expected to operate in an effective manner?

- Obviously, the aircraft accident response system can be improved (or generated) using the DFPM model of requirements.

The DFPM model has been developed to allow its requirements to evolve beyond prescriptive i.e. "command and obey" requirements and include principles of a goal-based and performance driven body of the system's expectations. The best practices are integrated into attributes of model requirements. The DFPM model enables the evaluation of the aircraft accident response system's overall effectiveness, as well as the intervention and recovery process successfulness in particular by the assessment of the system's compliance with requirements.

Using the DFPM model the existing aircraft accident intervention and recovery system is analysed in the following chapter based upon the assessment of conformance to the requirements for successful and effective aircraft accident response.

\subsection{Aircraft accident response system DFPM assessment discussion}

\subsubsection{Response system maturity}

The DFPM model-based functional analysis provided an insight into the level of compliance with the functional requirements identifying the necessary task, actions and activities that must be accomplished for successful aircraft accident intervention and efficient post-intervention recovery. The fundamental structure supporting the process of aircraft accident intervention and recovery can be considered as established, available and functioning. A statement is evidenced from the case study identifying the intervention and recovery forces $(\S 2.1, \S 2.2)$ and respecting the results of a fact-finding statistics oriented towards the provision of the system's functional chain (Table 1).

Aircraft accident intervention and following postintervention recovery are safety management functions. Since they cannot function and do not exist in an empty, or vacated space, a conceptual framework is needed. The architectural, structural and behavioural system foundation is laid down by the transposition of an international regulatory framework into the national legislation. The processes under discussion are governed by the Civil Aviation Act and subordinated Decree on the investigation of aircraft accidents, serious incidents and incidents and the Rules on logistics support to the aircraft accident and incident investigation body. The authority, duties, limits of responsibilities and competences of major decision-makers i.e. commanders and coordinators are specified in the National Protection and Rescue Plan in the Event of an Aircraft Accident, version 4.0 [16]. At the operational level, the authority, duties and responsibilities of the nominated post holders are defined in the mandatory safety and security related documentation of certified organizations involved in aircraft accident intervention and recovery. They are addressing, in particular, the management personnel in charge of safety and security, including the relationship and reporting lines between different parts and processes of the intervention (and to some extent) recovery system.

\subsubsection{Unaddressed issues of the response system}

The assessment against the DFPM model design requirements identified a common core gap. The gap can be closed by institutional and governing principle improvements:

- policy of overall responsibility of the Ministry of Transport to carry out the tasks of aircraft accident intervention and recovery (currently, this task is being carried out by the Civil Aviation Directorate on a volunteer basis),

- responsiveness by various departments of the Ministry of Transport (financial, legal, information, etc.),

- defragmentation of post holders for logistics support of the process of aircraft accident investigation and recovery at the cross-ministerial level, which would clear the availability shortcomings identified from the best practices point of view,

- powers to assume certain material (financial) commitments.

Furthermore, unaddressed system design issues, resulting in imperfect intervention and in particular recovery planning, became evident:

- a line of conduct and practices of relationships with the owner of a property (land) of an aircraft accident site,

- mode and best practices of interfering with the property of an aircraft accident site for the purposes of investigating the causes of an aircraft accident,

- means of protection of property of an aircraft accident site,

- standards defining the satisfactory post-recovery state of the property of an aircraft accident site,

- protocol of communication with the owner of the aircraft involved in an accident,

- mechanisms for operational access to (curative) financial resources during intervention and recovery, including the introduction of mechanisms for preventive financial resources allocation. 


\subsubsection{Scantiness of competences}

The assessment produced a critical safety-related finding of non-conformance with the qualification requirements for individuals and teams participating in the intervention. The personnel participating in the process of aircraft accident intervention and recovery is not sufficiently trained and to the point not adequately educated according to international rules and recommendations of the European Union legislation, the International Civil Aviation Organization (ICAO), and the European Civil Aviation Conference (ECAC). Educational deficiencies are leaving general safety culture impaired. An unsatisfying level of experience and skilfulness of participating personnel can be perceived due to the only sporadic full scale and realistic aircraft accident simulations. The finding is critical as it affects the crucial responsiveness of the system in terms of human resources capabilities, their availability and aptitude for adaptability, as well as in terms of mission executability. In addition to qualification currency assurance, regular and adequate training would enhance performances of a system in terms of response and execution time, as well as efficiency of operations, cooperation and coordination of combined actions. Simulations of an aircraft accident can be regarded as an instrument of the intervention and recovery plan verification, and an efficient methodology for a continual system development. They have the ability to facilitate the advancement in the domain of mission execution including operational unit-level mission-objective-oriented on-the-spot cooperation and coordination and tactical delegation of powers and duties.

\subsubsection{Logistical discontinuities}

Logistics and hardware, i.e. material resources, are facilitators of successful aircraft accident intervention and effective post-intervention recovery. Notwithstanding the existence of a system with established architecture, structure, and behaviour, irregularities and deficiencies accounted for in the field of logistics support result in discontinuation of aircraft accident response sequences. Remedial measures should improve the material resources and equipment available for aircraft accident intervention and recovery in general. Improvements should in particular provide the availability of:

- prompt transportation in all phases of intervention and recovery,

- adequate and interoperable communication equipment including the provision of on-site data access and transmission (cellular network based internet access),

- appropriate fire-fighting, rescue and personal protective equipment,

- storage facilities, particularly for post-recovery reconstruction of an aircraft involved.

\subsection{The process of transition from aircraft accident intervention to recovery}

\subsubsection{The problem of transition}

The problem of the transition from aircraft accident intervention to recovery emerged amid the DFPM conformance assessment. Aircraft accident intervention and recovery are by their definition separated activities, but they are at the same time interdependent. Simultaneously, the process of an aircraft accident investigation is performed for the reconstruction of the accident and the determination of the causes of the accident. The problem importance intensifies as it is the key element of reactive safety management derived from a prompt and effective investigation of an aircraft accident. The accident investigation itself depends on effective information gathering about the probable causes of the accident and the contributing factors identifiable on-site and on-the-wreckage. The general problem of transition narrows down to the problem of a milestone or a moment appropriate for the transition from aircraft accident intervention to recovery determination, as the transition itself is not exactly defined by the system's structural or behavioural design features.

Recovery, defined as an activity to eliminate the consequences of an aircraft accident and in its successive phase the activity of re-establishing the pre-accident state, cannot start before accident intervention is completed. It cannot even start before the aircraft accident investigation reaches the phase in which all obtainable information regarding the aircraft crash site and aircraft wreckage is gathered. At least the authority for approval, if not the authority deciding on the commencement of recovery, must be systematically delegated to the investigator in charge of a particular aircraft accident on-site investigation. Seconded to the decision-making authority should be the head of the on-site intervention subsystem, i.e. the group of intervening units whose support in the decision-making process should prevent interference between aircraft accident intervention and recovery activities.

If aircraft accident recovery commences prematurely, a non-negligible possibility exists that information about the aircraft crash site and about aircraft wreckage obtainable exclusively on-site and on-thewreckage can be non-returnable and forever lost. Considering that the personnel involved in the aircraft recovery do neither possess the knowledge nor the experience in the subject of the aircraft accident investigation, clues about the probable causes of the aircraft accident and factors only contributing to the identification on the spot might be erased unknowingly and unintentionally. There is even a chance that the aircraft accident investigator is deliberately denied an on-site obtainable but crucial information through an actually unlawful action masked by the recovery activity. 


\subsubsection{Transition criteria}

The amalgamation of aircraft accident intervention, investigation and recovery processes into a coherent response system would significantly increase the efficiency of reactive (post occurrence) safety management. However, this amalgamation effectiveness depends on the transition from aircraft accident intervention to recovery. To make the decision-making about the transition from aircraft accident intervention to recovery a predictable and manageable process, its procedures and final provisions must be based on the transition criteria. Since they have to assure an entirely feasible on-site aircraft accident investigation provable by completely established facts obtainable from the aircraft accident site and wreckage, the transition criteria actually represent a proactive approach to aviation safety assurance. The set of transition criteria is combined by:

- the response time of an aircraft accident investigation team,

- the on-site aircraft accident investigation execution time driven by:

- availability of human resources,

- availability of technical resources i.e. hardware,

- availability of transportation,

- accessibility of the accident site,

- the level of aircraft accident investigation procedure perfection including the level of experience and expertness of investigators,

- the level of intervention process technical measure perfection assuring additional damage prevention, including prompt documentation on interventioninduced but unavoidable additional damage to the accident site and/or aircraft wreckage,

- the efficiency of logistics support to the investigation process,

- the availability of storage facilities for the off-site reconstruction of the aircraft wreckage distribution; namely, a successful technical investigation of an aircraft accident derives its conclusions from the relative position, pattern and distribution of wreckage and parts or objects on board an aircraft that therefore has to remain unchanged during investigation,

- the location of the aircraft accident; if the accident site is on or in the vicinity of the airport, it is reasonable to expect an appropriate level of experience and expertise of intervention and recovery units,

- the level of total response system perfection.

The issues of the transition from aircraft accident intervention to recovery introduce complexity into the aircraft accident response system, which increases either the execution time or the required resources and therefore unavoidably generates additional costs. One might argue that swift completion of aircraft accident recovery has a significant impact on "good reputation" of the airline involved in an accident. The promptness of an accident traces disposal from the physical world as well as deletion from the passenger memory might drive the airline post-accident income. However, in a large-scale aircraft accident this burden of added complexity actually facilitates the successfulness of an aircraft accident investigation which results through reactive safety management in increased aviation safety. Emergent preventive costs added by the complexity of reactive aviation safety management introduced are therefore excusable (theoretically as long as they do not exceed the total costs of an aircraft accident [17]).

Small-scale aircraft accidents represent another aspect in the discussion about the transition from aircraft accident intervention to recovery. Actually, the processes of aircraft accident intervention and recovery run almost simultaneously in cases of a small aircraft accident, and are frequently performed by the same responding unit. No matter how, one must not seek for leisure shortcutting in aviation safety assurance.

\section{CONCLUSION}

The Slovenian aircraft accident response system effectiveness was investigated by interviewing mostly experienced personnel of response system operational entities. On the basis of the collective experience of the interviewees, the deficiencies in the procedures of transition from an aircraft accident intervention to recovery were identified as paramount.

A DFPM (Design, Functionality, Performance, and Mission) model of aircraft accident response system requirements has been developed according to which the processes of intervention, investigation, and recovery should accomplish their objectives successfully, reliably, and efficiently. The model of response system requirements was used for a systematic assessment of the processes of aircraft accident intervention and recovery existing in Slovenia in terms of design, functionality, performance, and mission execution.

Using the DFPM model, the maturity of the Slovenian aircraft accident response system was ascertained. However, unaddressed institutional and governing issues, scantiness of operational personnel competences as well as logistical discontinuities emerged. Based on the non-conformances to the system requirements, remedial measures are proposed and detailed to enhance the Slovenian aircraft accident response system. Accordingly, the aptness of problem issue identification and the aptness of corrective actions development prove the methodological correctness and practicability of the DFPM model of aircraft accident response system requirements.

The assessment of an aircraft accident response system demonstrated the power to prove (hypothesis 
set for the research) that the role and importance of the safety aspect of the transition from aircraft accident intervention to recovery is to considerably contribute to the enhancement of aviation safety. Namely, an incorrect or inappropriate transition from the process of aircraft accident intervention to recovery can degrade or even deny the aircraft accident investigation ability to reveal the accident causes and contributing factors obtainable only on-site and on-the-wreckage. An unsuccessful and ineffective aircraft accident investigation results in the inability to prevent accident reoccurrence making reactive safety management incapacitated for the aviation safety enhancement provision. On the basis of assessment findings the criteria necessary for the determination of the transition from aircraft accident intervention to recovery were derived. The set of prerequisites for the aircraft accident investigation aptness to react with measures for accident reoccurrence prevention is secured, maintaining in the process successfulness of an aircraft accident intervention as well as efficiency of the following recovery.

\section{Mag. FRANC ŽELJKO ŽUPANIČ}

E-mail: zupanic@sloveniacontrol.si

Kontrola zračnega prometa Slovenije, d.o.o.

Kotnikova 19a, 1000 Ljubljana, Slovenija

\section{Dr. MAJA MEŠKO}

E-mail: maja.mesko@fm-kp.si

Univerza na Primorskem, Fakulteta za management

Cankarjeva 5, 6000 Koper, Slovenija

Dr. IZTOK PODBREGAR

E-mail: iztok.podbregar@fvv.uni-mb.si

Univerza v Mariboru, Fakulteta za varnostne vede

Kotnikova 8, 1000 Ljubljana, Slovenija

\section{POVZETEK}

\section{METODOLOGIJA VREDNOTENJA SISTEMA ODZIVAJA NA LETALSKO NESREČO}

Proučevana je sposobnost učenja na napakah, ki so povzročile letalsko nesreče, saj se število priložnosti za učenje zmanjšuje $z$ upadanjem števila letalskih nesreč. Predmet raziskave je primer $z$ nevarnostnim potencialom, $k i$ predvideva, da procesa intervencije in sanacije po letalsk nesreči degradirata zmožnost procesa preiskovanja letalske nesreče, da z ugotovljenimi vzroki za nesrečo poveča raven varnosti $v$ letalstvu. Evalviran je slovenski sistem odzivanja na letalsko nesrečo. Za namen evalvacije uspešnosti intervencije in učinkovitost sanacije po letalski nesreči je predstavljen razvit model zahtev za sistem odzivanja na letalsko nesrečo. Na podlagi neskladij, ugotovljenih z modelom zahtev, so predlagani korektivni ukrepi, ki bodo zagotavljali, da bo sistem odzivanja na letalsko nesrečo sposoben izboljševati varnost $v$ letalstvu. Na podlagi ugotovitev presoje pa so izpeljana merila za definicijo trenutka oziroma pogojev prehoda iz intervencije $v$ sanacijo po letalski nesreči na način, ki ne bo negativno vplival na uspešnost in učinkovitost procesa preiskovanja letalske nesreče.

\section{KLUČNE BESEDE}

letalska nesreča, sistem odzivanja, intervencija, sanacija, preiskava, krizno upravljanje

\section{LITERATURE}

[1] Rose, A.: "Free lessons" in aviation safety, Aircraft Engineering and Aerospace Technology, Vol. 76, No. 5, 2004.

[2] Athiniotis, N., Lombardo, D., Clark, G.: On-site aspects of a major aircraft accident investigation, Engineering Failure Analysis, Vol. 16, No. 7, 2009

[3] Barbry, F.Y.: Exposure risks and intervention possibilities in solution criticality accidents, Transactions of the American Nuclear Society (USA), Vol. 63, 1991.

[4] Holsti, K.: International Politics: A Framework of Analysis, Prentice Hall, New Jersy, 1995

[5] Nickson, D., Siddons, S.: Project management disasters \& how to survive them, K. Page, London, Philadelphia, 2006

[6] Rosenthal, U., Charles, M., Hart, P.: The World of Crises and Crisis Management, in Rosenthal, U., Charles, M., Hart, P. Coping with Crises: The management of disaster, riots and terrorism, Charles C Thomas, Springfield, IL, 1989

[7] Rosenthal, U., Kouzmin, A.: Crises and Crisis Management: Toward Comprehensive Government Decision Making, Journal o Pubic Administration Research \& Theory, Vol. 7, No. 2, 1997, pp. 277-304

[8] Salmon, T., Alkadari, R.: Crises, Crisis Management an Crisis Prevention, in R. Carey and T. Salmon (Eds.), International Security in the Modern World, St. Martin's Press, New York, 1992

[9] Dubrovski, D.: Krizni management in prenova podjetja, Fakulteta za management, Koper, 2004

[10] Novak, B.: Krizno komuniciranje in upravljanje nevarnosti: priročnik za krizne odnose z javnostmi v praksi, Gospodarski vestnik, Ljubljana, 2002

[11] Sistem varstva pred naravnimi in drugimi nesrečami. Available at http://www.sos112.si/slo/page.php?src= sv1.htm, 2011

[12] Mei, R., Tingdi, Z., Xiaolei, L.: Research on accident rehearsal modeling, Acta Aeronautica et Astronautica Sinica, Vol. 29, No. 6, 2008.

[13] Zhang, D.M., Lee, M., Wong, W-Y.: A knowledge-based approach to design of intervention strategies for incidents, Systems, Man, and Cybernetics, IEEE SMC '99, Vol. 6, 1999

[14] Grady, R.: Practical Software Metrics for Project Management and Process Improvement, Prentice Hall. 1992.

[15] Ortega, M., María Pérez, M., Rojas, T.: Construction of a Systemic Quality Model for Evaluating a Software, Software Quality Journal, Vol. 11, No. 3, 2004.

[16] Vlada Republike Slovenije, Državni načrt zaščite in reševanja ob letalski nesreči, Ministrstvo za obrambo, Uprava RS za zaščito in reševanja, Version 4.0, 2004.

[17] Cokorilo, O., Gvozdenovic, S., Vasov, L., Mirosavljevic, P.: Costs of Unsafety in Aviation, Technological and Economic Development of Economy, Vol.16, 2010. 